\title{
ANALISIS FAKTOR- FAKTOR STRESSOR TERHADAP STRES KERJA DAN KINERJA KARYAWAN KEMENTERIAN KEUANGAN
}

\author{
Ami Pujiwati dan Etty Susanty \\ Fakultas Ekonomi Jurusan Manajemen Universitas Terbuka \\ ami@ut.ac.id
}

\begin{abstract}
The purpose of this study was to determine the factors that become a stressor to stress the work and employee performance and to determine the effect of work stress on employee performance Secretariat General of the Ministry of Finance. This research was conducted on the employee group III at 5 (five) units which are under Sekretariatan General of the Ministry of Finance of the Republic of Indonesia. The analytical method used path analysis using SEM analysis tools SmartPLS. The sample used in the study amounted to 150 respondents. The results showed that the lack of authority in order to carry out the responsibilities of being a major factor in generating stress (stressors) whereas the difficulty to get along with superiors, they cause work stress. While taking risks and thinking hard to always be able to work with either a major factor in improving employee performance. Stressor in the office of the Secretary General of the Ministry of Finance significantly positive effect on employee stress, while in the office of the Secretary General of the Ministry of Finance stressor does not significantly affect the employee performance and job stress did not significantly affect performance.
\end{abstract}

Key words: stressor, stress, employee performance

\begin{abstract}
Abstrak: Tujuan penelitian ini adalah untuk mengetahui faktor-faktor yang menjadi stressor terhadap stress kerja dan kinerja karyawan serta untuk mengetahui pengaruh stres kerja terhadap kinerja karyawan Sekretariat Jenderal Kementerian Keuangan RI. Penelitian ini dilakukan pada karyawan golongan III pada 5 (lima) unit yang berada di bawah Sekretariatan Jenderal Kementerian Keuangan Republik Indonesia. Metode analisis yang digunakan analisis jalur dengan menggunakan alat analisis SEM SmartPLS. Sampel yang digunakan dalam penelitian berjumlah 150 responden. Hasil penelitian menunjukkan bahwa kekurangan wewenang untuk bisa melaksanakan tanggung jawab menjadi faktor utama dalam pembangkit stress (Stressor) sedangkan kesulitan bergaul dengan atasan menjadi faktor penyebab stress kerja. Sementara mengambil resiko dan berpikir keras untuk selalu dapat bekerja dengan baik menjadi faktor utama meningkatkan kinerja karyawan. Stressor di kantor Sekjen Kemenkeu berpengaruh positif secara signifikan terhadap stress kerja karyawan, sedangkan stressor di kantor Sekjen Kemenkeu tidak berpengaruh secara signifikan terhadap kinerja karyawan dan stres kerja tidak berpengaruh secara signifikan terhadap kinerja.
\end{abstract}

Kata kunci: stressor, stress kerja, kinerja karyawan

\section{PENDAHULUAN}

Tujuan dan harapan karyawan terhadap perusahaan seringkali terjadi kesenjangan (gap) dengan realita yang ada. Kesenjangan ini dapat menimbulkan masalah-masalah yang 
terkait dengan Sumber Daya Manusia (SDM) yang berada di dalam perusahan. Masalahmasalah SDM yang timbul tentunya dapat mempengaruhi kinerja karyawan.

Kinerja karyawan merupakan salah satu kunci keberhasilan suatu perusahaan yang secara langsung atau tidak langsung memberi konstribusi pada perusahaan, yang meliputi pemangku kepentingan eksternal (stakeholder) dan kepentingan internal (karyawan) yang dimiliki oleh perusahaan. Guna memperoleh kinerja yang optimal dari keberadaan karyawan dalam perusahaan maka perusahaan perlu menetapkan strategi yang tepat, yaitu dengan memikirkan bagaimana mengelola karyawan agar mencapai tujuan perusahaan yang telah ditetapkan (Mangkuprawira, 2009).

Kinerja karyawan pada dasarnya ditentukan oleh tiga hal yakni kemampuan, keinginan dan lingkungan. Marifah (2004) telah melakukan penelitian tentang ukuran dalam kinerja karyawan meliputi: kuanlitas, kuantitas, pengetahuan, keandalan, kehadiran, dan kerjasama. Agar mempunyai kinerja yang baik, seseorang harus mempunyai keinginan yang tinggi untuk mengerjakan serta mengetahui pekerjaannya. Ketidaksesuaian antara pekerjaan dan kemampuan seringkali memicu timbulnya stres dalam pekerjaan. Pekerjaan yang tidak sesuai dengan pendidikan dan kemampuan karyawan dapat memicu timbulnya stres dalam diri karyawan. Ditambah beban kerja yang berlebihan dan ketersediaan waktu yang tidak cukup dapat semakin cepat menjadi pemicu terjadinya stres. Stres merupakan salah satu penyebab menurunnya kinerja dan produktivitas karyawan.

Kata stress berasal dari bahasa Latin Stringer yang berarti menarik secara kencang. Menurut definisi Canadian Centre for Occupational Health and Safety (1999), stres adalah tekanan dari luar yang bias membuat seseorang merasa tertekan. Tekanan yang membuat orang stress adalah tekanan yang sifatnya mengancam (threaten), tekanan yang sifatnya menakutkan atau mengerikan (scare), tekanan yang sifatnya mengkhawatirkan (worry), dan tekanan yang sifatnya menyakitkan atau yang menusuk. Ivancevich (1987) menyatakan stress merupakan interaksi antara individu dengan lingkungannya. Stres juga sering didefinisikan sebagai respon tidak spesifik dari tubuh manusias terhadap lingkungan ekternalnya (Jams, 1986).

Dalam dunia kerja sering muncul berbagai masalah sehubungan dengan stres kerja. Baik disadari maupun tidak, kondisi-kondisi pekerjaan dapat menimbulkan stres pada diri karyawan. Stres mempunyai posisi yang penting dalam kaitannya dengan produktivitas SDM, finansial dan materi. Stres di tempat kerja telah membebankan perusahaan dengan biaya yang mahal. Suatu studi mengungkapkan bahwa perusahaan kehilangan penghasilan sebesar US\$68 milyar per tahun karena turunnya produktivitas sebagai efek dari stres karyawan (Gibson.et.al, 1993). Biaya-biaya tersebut termasuk tunjangan kesehatan (ketika sakit), biaya perawatan inap dan opname, dan biaya-biaya yang berkaitan dengan produktivitas yang menurun.

Menurut Milbourn (2006) pembangkit stres kerja (stressor) dapat dilihat dari enam faktor yakni kebingungan peran, konflik peran, ketersediaan waktu, kelebihan beban kerja, pengembangan karir dan tanggung jawab. Jadi stres kerja dapat terjadi jika tuntutan kerja melebihi kemampuan atau kapasitas yang dimiliki seorang karyawan. Oleh karena itu, perusahaan perlu mengetahui seberapa besar tingkat stres karyawannya. Setelah mengetahui tingkat stres karyawannya maka perusahaan dapat mengambil tindakan untuk mengatasi stres yang dialami karyawannya sehingga karyawan dapat bekerja secara produktif. 
Rahmawati (2009) menyatakan dalam penelitiannya tentang faktor-faktor penyebab stress kerja (stressor) karyawan PT BRI (Persero) Tbk Bogor terdiri dari tuntutan tugas, tuntutan peran, tuntutan hubungan antar pribadi, struktur organisasi, kepemimpinan organisasi dan tahap hidup organisasi. Shaikh et al. (2011) dalam risetnya untuk manager pabrik di Pakistan menyatakan bahwa konflik pekerjaan dan ketidakjelasan peran berhubungan positif dan signifikan dengan stress kerja manajer dan stress kerja berhubungan negatif dan signifikan dengan kepuasan kerja. Makhbul (2009) dalam jurnal "Work Stress Issues in Malaysia" mengemukakan bahwa kesehatan, tempat kerja, shift kerja, sistem kelembaban dan faktor jam kerja berhubungan signifikan dengan hasil stress kerja.

Pegawai Negeri Sipil (PNS) merupakan tulang punggung pemerintah dalam menyelenggarakan tugas pemerintah dan pembangunan. Peran tersebut harus dijalankan dengan efisien, efektif, bersih dan berwibawa. Upaya dalam perwujudan pelayanan yang maksimal dan profesional dalam organisasi seringkali memicu timbulnya stres dalam pekerjaan. Secara umum, masyarakat sering memandang bahwa menjadi PNS adalah pekerjaan yang paling menyenangkan. Beban pekerjaannya tidak berat dan terlihat santai dalam melakukan pekerjaannya. Dalam beberapa kasus hal ini tidak dapat dipungkiri, namun demikian kenyataannya, banyak PNS yang mengalami stres kerja.

Kementerian Keuangan Republik Indonesia (Kemenkeu RI) memiliki tugas yang sangat berat yakni menyelenggarakan urusan di bidang keuangan dan kekayaan negara dalam pemerintahan untuk membantu Presiden dalam menyelenggarakan pemerintahan negara. Selain itu Kemenkeu RI memiliki visi penting yakni "Menjadi Pengelola Keuangan dan Kekayaan Negara yang Dipercaya dan Akuntabel dan terbaik di tingkat regional untuk Mewujudkan Indonesia yang Sejahtera, Demokratis, dan Berkeadilan".

Selain tugas, tentunya Sekretariat Jenderal memiliki fungsi yang lain. Fungsi tersebut yakni sebagai koordinasi kegiatan Kementerian Keuangan, koordinasi dan penyusunan rencana dan program Kementerian Keuangan, pembinaan dan pemberian dukungan administrasi yang meliputi ketatausahaan, kepegawaian, keuangan, kerumahtanggaan, arsip, dan dokumentasi Kementerian Keuangan, pembinaan dan penyelenggaraan organisasi dan tata laksana, kerja sama, dan hubungan masyarakat, koordinasi dan penyusunan peraturan perundang-undangan dan bantuan hukum, penyelenggaraan pengelolaan barang.

Dilihat dari tugas karyawan Sekretariat Jenderal Kemenkeu yang begitu beragam, maka sudah tentu beban kerja yang mereka rasakan cukup berat. Kondisi seperti ini menuntut PNS pada kementrian tersebut dituntut memiliki keterampilan khusus untuk menangani pekerjaan tersebut. Tidak menutup kemungkinan stres dapat dialami oleh karyawan di lingkungan Sekretariat Jenderal Kemenkeu yang harus memiliki keterampilan khusus dan tanggung jawab tupoksi yang cukup berat.

Berdasarkan uraian diatas, penulisan artikel ini bertujuan untuk menganalisis: (1) faktor-faktor yang menjadi stressor bagi stress kerja dan kinerja karyawan Sekretariat Jenderal Kementerian Keuangan RI dan (2) pengaruh stres kerja terhadap kinerja karyawan Sekretariat Jenderal Kementerian Keuangan RI.

\section{METODE}

Dari uraian mengenai analisis faktor-faktor stressor terhadap stres kerja karyawan dan kinerja karyawan, model yang dianalisis pada penelitian ini disajikan pada Gambar 1. Penelitian ini dilakukan pada Sekjen Kementerian Keuangan Republik Indonesia. 
Respoden penelitian adalah karyawan golongan III pada 5 (lima) unit yang berada di bawah Sekretariatan Jenderal Kementerian Keuangan Republik Indonesia.

Desain penelitian ini adalah survei dengan tujuan untuk menganalisis satu variabel atau lebih variabel bebas terhadap variabel terikat. Pengumpulan data dilakukan dengan kuesioner yang berisi pernyataan-pernyataan mengenai stres kerja yang merupakan adaptasi dari pengukuran penelitian Milbourn (2006) dan kinerja yang dikembangkan oleh Marifah (2004).

Untuk menganalisis faktor-faktor stressor terhadap stres kerja karyawan dan kinerja karyawan digunakan analisis jalur dengan menggunakan program Partial Least Square (PLS). Besar ukuran sampel untuk metode analisis SEM dengan PLS adalah 30 - 100 tergantung pada jumlah indikator yang digunakan dalam seluruh variabel laten (Hair, 2006). Penelitian ini menggunakan 14 variabel manifest, sehingga jika mengacu pada teori Hair maka total sampel yang diperlukan sebesar 140 orang responden, dengan perhitungan sebagai berikut:

$$
\begin{aligned}
& n=\text { jumlah variabel manifest } \times 10 \\
& n=14 \times 10 \\
& n=140
\end{aligned}
$$

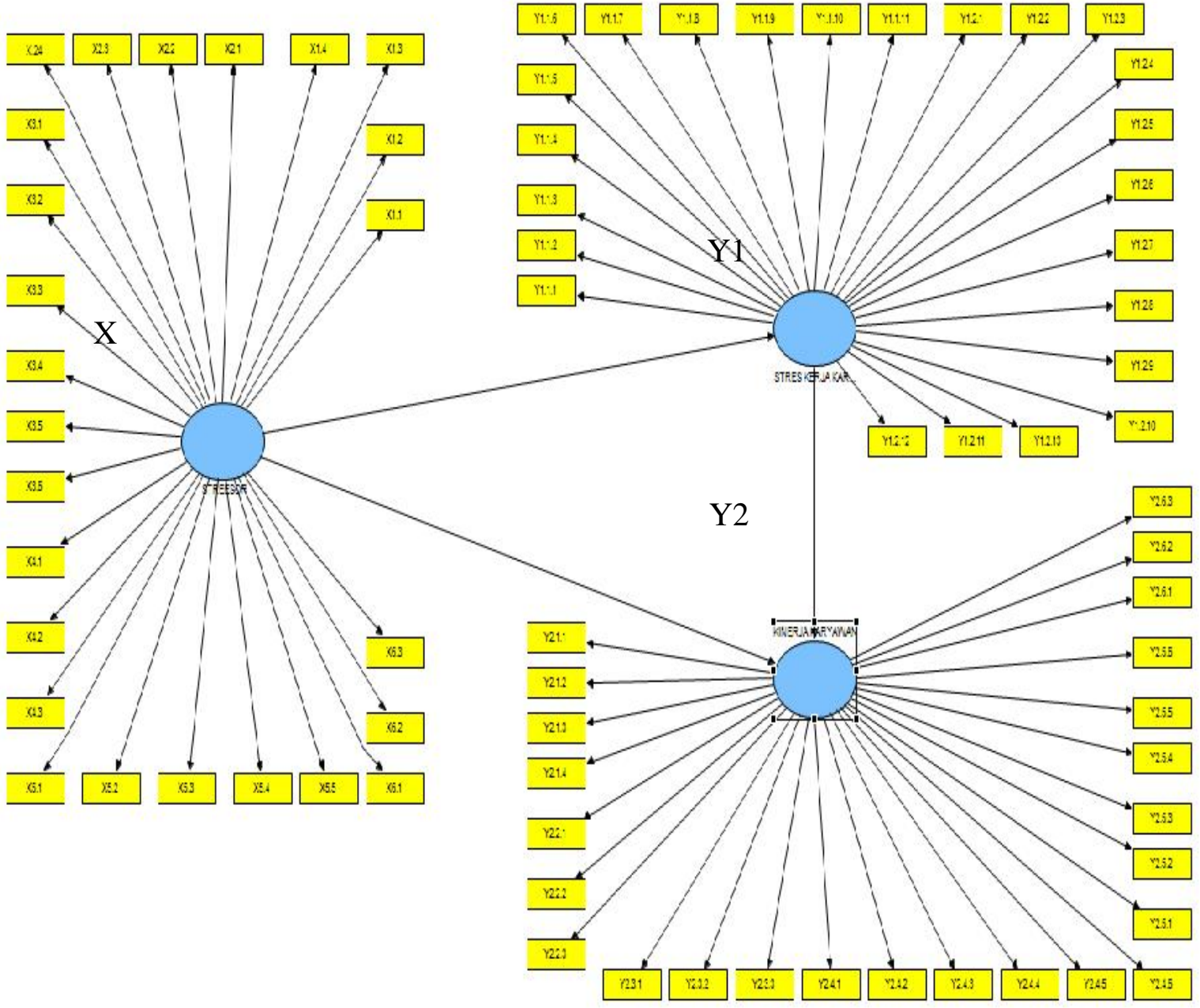

Gambar 1. Model Penelitian 
Keterangan Gambar:

X : Stressor terdiri dari X1-X6 (role ambiguity, role conflict, time availability, role overload, carrer development, dan responsibility)

X1.1 s.d. X1.4: mengerjakan tugas, kekurangan wewenang, mengetahui kinerja yang diharapkan, dan memahami pekerjaan terhadap pencapaian target perusahaan

X2.1 s.d. X2.4 : kejelasan tugas dan pekerjaan, posisi terjepit di antara atasan dan teman sekerja, terdapat instruksi kerja, dan terdapat konflik pekerjaan

X3.1 s.d. X3.6 : membawa pulang pekerjaan ke rumah, menghabiskan waktu untuk mengikuti rapat-rapat, diberi banyak tugas, mendapat tugas pekerjaan yang tak mungkin dapat diselesaikan dalam satu hari normal, merasa memiliki waktu untuk mengambil cuti istirahat, dan memiliki cukup pelatihan atau pengalaman untuk menjalankan tugas pekerjaan.

X4.1 s.d. X4.3 : tuntutan terhadap kualitas pekerjaan, tuntutan terhadap kuantitas, dan tuntutan pekerjaan terhadap kemampuan yang miliki.

X5.1 s.d. X5.5 : mendapat kesempatan untuk memajukan perusahan, mengharap promosi, meningkatkan karier, memiliki sedikit peluang untuk maju, dan merasa karier sudah buntu.

X6.1 s.d X6.3 : dibebani tanggung jawab untuk membimbing karyawan lain, diberi tanggungjawab untuk berurusan dengan orang-orang daripada ke pekerjaan, dan bertanggung jawab terhadap masa depan karyawan lain.

Y1 : Stres kerja karyawan terdiri dari Y1.1 (emosional) dan Y1.2 (sikap/perilaku)

Y2 : Kinerja karyawan terdiri dari Y2.1 (keandalan), Y2.2 (kehadiran), Y2.3 (kerjasama), Y2.4 (kualitas pekerjaan), Y2.5 (kuantitas pekerjaan) dan Y2.6 (pengetahuan)

\section{HASIL DAN PEMBAHASAN}

Responden yang digunakan dalam penelitian ini berjumlah 150 orang, yang mewakili 5 (lima) unit yang berada di bawah Sekretariatan Jenderal Kementerian Keuangan Republik Indonesia dan berasal dari golongan III.

Tabel 1. Jumlah Sampel Karyawan Sekretariat Jenderal Kemenkeu

\begin{tabular}{clcc}
\hline No & \multicolumn{1}{c}{ Nama Unit Sekretariat Jenderal } & $\begin{array}{c}\text { Jumlah } \\
\text { Karyawan }\end{array}$ & $\begin{array}{c}\text { Jumlah } \\
\text { Sampel }\end{array}$ \\
\hline 1. & Pusat Sistem Informasi dan Teknologi & 177 & 30 \\
& Keuangan (Pusintek) & & \\
2. & Pusat Layanan Pengadaan Secara Elektronik & 37 & 30 \\
3. & Biro Sumber Daya Manusia (SDM) & 169 & 30 \\
4. & Biro Hukum & 60 & 30 \\
5. & Biro Umum & 155 & 30 \\
& $\quad$ Total Jumlah Sampel & & 150 \\
\hline
\end{tabular}

Sumber: Kemenkeu 2013. 
Responden yang diambil sebagai sampel sebanyak 150 karyawan dan diperinci berdasarkan jenis kelamin, usia, status, pendidikan terakhir, golongan dan masa kerja. Ke enam aspek demografi tersebut mempunyai peran penting dalam menentukan tingkat stress dan kinerja karyawan. Gambaran karakteritik responden berdasarkan keenam aspek demografi dapat disajikan pada Tabel 2.

Tabel 2. Karakteristik Responden Berdasarkan Jenis Kelamin, Usia, Tingkat Pendidikan dan Masa Kerja

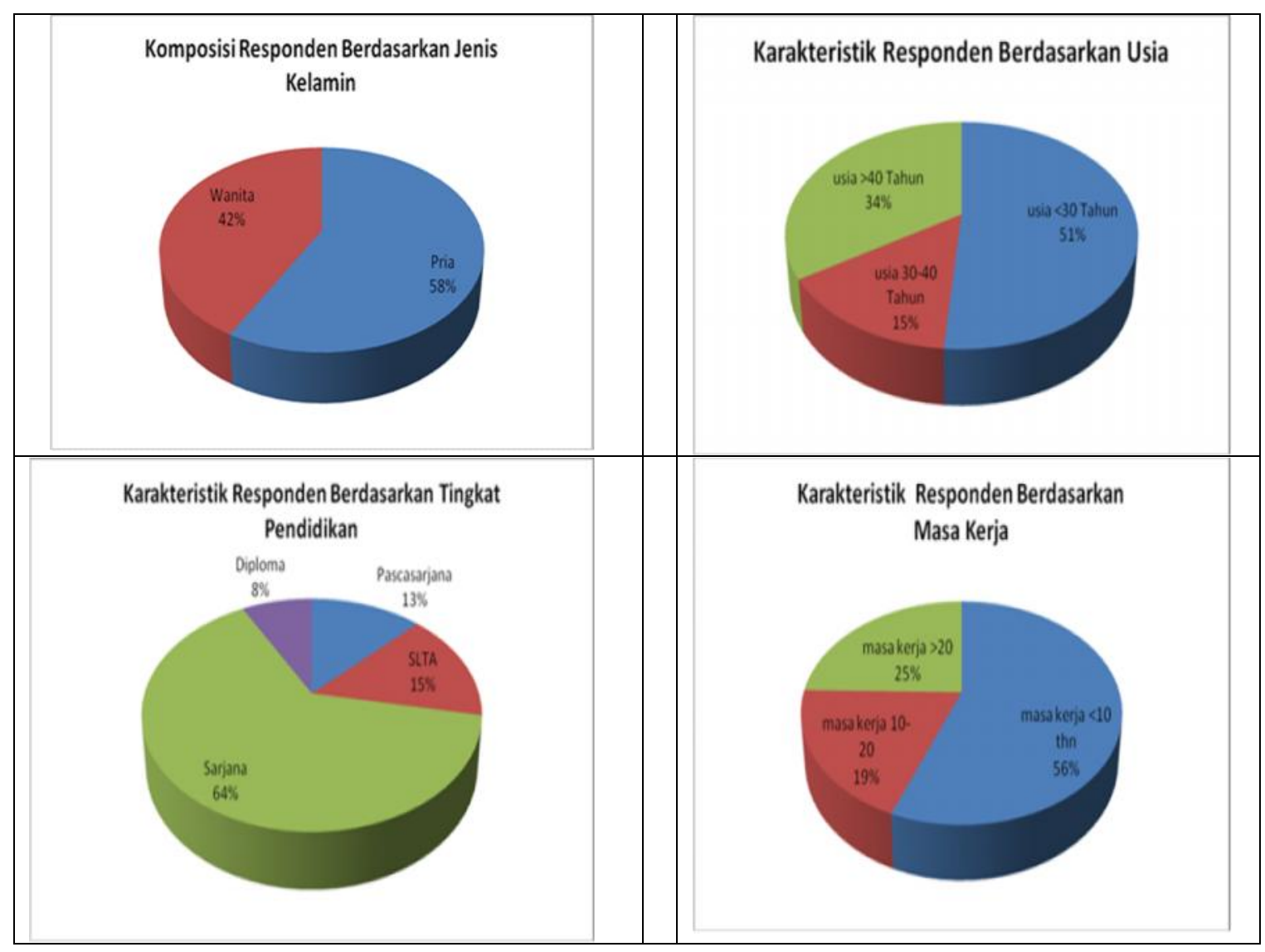

Tabel 3. Karakteristik Responden Berdasarkan Golongan dan Status Pernikahan

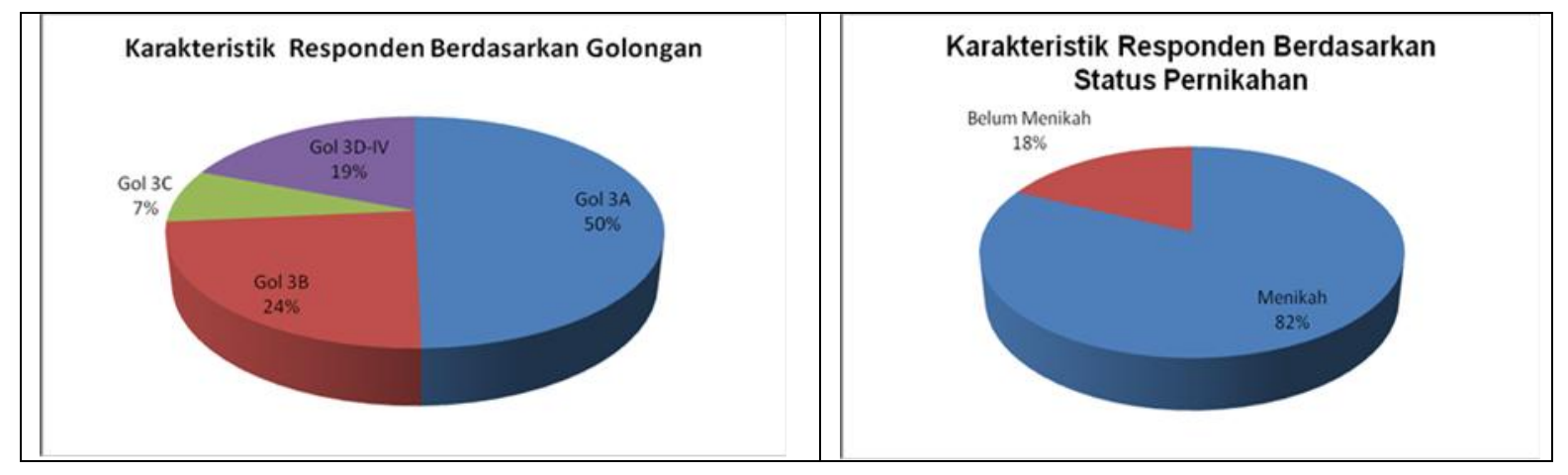


Analisis Partial Least Square (PLS). Metode penelitian menggunakan analisis kuantitatif dengan menggunakan perhitungan statistik sebagai dasar analisis. Proses penarikan sampel dilakukan dengan menggunakan metode probabilitas sampling sample yaitu penarikan secara acak. Untuk keperluan penolakan atau penerimaan hipotesis, digunakan taraf signifikansi $\mathrm{P}<0.05$.

Metode analisis dalam penelitian ini menggunakan analisis jalur dengan SEM SmartPLS. Penggunaan alat analisis ini sangat beralasan karena metode analisis powerfull dan tidak didasarkan pada banyak asumsi. Data juga tidak harus berdistribusi normal multivariate (indikator dengan skala kategori, ordinal, interval sampai ratio dapat digunakan pada model yang sama), sampel tidak harus besar. Selain itu, dapat mengkonfirmasi teori, sekaligus dapat menjelaskan ada atau tidaknya hubungan antar variabel laten.

Pengujian terhadap model dengan menggunakan analisis SEM SmartPLS dilakukan dalam 2 (dua) tahap evaluasi yaitu outer model dan inner model. Untuk evaluasi outer model dilakukan berdasarkan 4 (empat) kriteria yaitu convergent validity, discriminat validity, Average Variance Extracted (AVE) dan composite reliability (Ghozali, 2008).

Tabel 4. Kriteria dan Standarisasi dalam Evaluasi Outer Model - Refleksi

\begin{tabular}{|c|c|c|}
\hline Kriteria & Standar & Keterangan \\
\hline $\begin{array}{l}\text { Converage validity } \\
\text { (Reliabilitas indikator) }\end{array}$ & $\begin{array}{l}\text { Nilai loading }>0.50 \\
\text { Chin (1998) menyatakan jika } \\
\text { di bawah 0.50 maka indikator } \\
\text { harus di drop }\end{array}$ & $\begin{array}{l}\text { Menilai kekuatan indikator } \\
\text { dalam merefleksikan konstruk } \\
\text { laten }\end{array}$ \\
\hline Discriminat validity & $\begin{array}{l}\text { Nilai cross loading } \\
\text { korelasi indikator ke variabel } \\
\text { laten nya lebih besar dari } \\
\text { variabel laten- laten lain }\end{array}$ & $\begin{array}{l}\text { Mengukur ketepatan model } \\
\text { refleksi }\end{array}$ \\
\hline $\begin{array}{l}\text { Composite reliability } \\
\left(\rho_{c}\right)\end{array}$ & $\rho_{\mathrm{c}}>0,6$ & $\begin{array}{l}\text { kestabilan dan konsistensi } \\
\text { internal indikator yang baik }\end{array}$ \\
\hline
\end{tabular}

Sumber: Ghozali, 2008

Selanjutnya, menilai inner model adalah mengevaluasi pengaruh antar variabel laten dan pengujian hipotesis. Model struktural dievaluasi dengan menggunakan R-square untuk variabel endogen dan membandingkan $t_{\text {hitung dengan }} t_{\text {tabel }}$ ( $t_{\text {tabel }}$ pada tingkat kepercayaan $95 \%$ adalah 1.96 ).

\section{Evaluasi Outer Model - Reflektif}

1. Convergent Validity (Reliabilitas Indikator). Reliabilitas indikator dicerminkan dari nilai loading factor yang merefleksikan kekuatan interelasi antara variabel laten pembangkit stress (stressor), stress kerja dan kinerja karyawan terhadap masingmasing variabel indikatornya. Pada bagian ini, terdapat 2 (dua) tahap pen-drop-an terhadap indikator yang mempunyai nilai loading faktor $<0,05$. Hasil pen-drop-an dapat dilihat pada Tabel 5 di bawah ini. 
Tabel 5. Hasil Dua Tahap Pen-drop-an Terhadap Indikator Yang Mempunyai Nilai Loading Factor < 0,05)

\begin{tabular}{|c|c|c|c|c|}
\hline \multirow{2}{*}{$\begin{array}{l}\text { Laten } \\
\text { Stressor }(\mathrm{X})\end{array}$} & \multicolumn{2}{|c|}{ Indikator } & \multirow{2}{*}{$\begin{array}{c}\text { Drop 1 } \\
\mathrm{X} 1.3, \mathrm{X} 1.4\end{array}$} & \multirow{2}{*}{$\begin{array}{c}\text { Drop 2 } \\
\text { X1.1 }\end{array}$} \\
\hline & Role Ambiguity (X1) & $\mathrm{X} 1.1-\mathrm{X} 1.4$ & & \\
\hline & Role Conflict (X2) & $\mathrm{X} 2.1-\mathrm{X} 2.4$ & $\mathrm{X} 2.1$ & Tidak ada \\
\hline & Role Overload (X3) & X3.1-X3.6 & X3.1; & Tidak ada \\
\hline & & & X3.2; & \\
\hline & & & $\begin{array}{l}\text { X3.4; } \\
\text { X3.5; X3.6 }\end{array}$ & \\
\hline & $\begin{array}{l}\text { Time Availability } \\
\text { (X4) }\end{array}$ & $\mathrm{X} 4.1-\mathrm{X} 4.3$ & $\mathrm{X} 4.2$ & Tidak ada \\
\hline & $\begin{array}{l}\text { Carrer Development } \\
\text { (X5) }\end{array}$ & X5.1-X5.5 & $\begin{array}{l}\text { X5.1; } \\
\text { X5.3; X5.4 }\end{array}$ & $\mathrm{X} 5.5$ \\
\hline & Resposibility (X6) & X6.1-X6.3 & $\begin{array}{l}\text { X6.1 - } \\
\text { X6.3 }\end{array}$ & X6.1-X6.3 \\
\hline \multirow{5}{*}{$\begin{array}{l}\text { Stres Kerja } \\
\text { Karyawan (Y1) }\end{array}$} & Emosional (Y1.1) & Y1.1.1 - & Y1.1.2; & Tidak ada \\
\hline & & Y1.1.11 & $\begin{array}{l}\text { Y1.1.8; } \\
\text { Y1.1.9; } \\
\text { Y1.1.10; } \\
\text { Y1.1.11 }\end{array}$ & \\
\hline & Sikap/Perilaku (Y1.2) & Y1.2.1 - & Y1.2.1; & Tidak ada \\
\hline & & Y1.2.12 & Y1.2.2; & \\
\hline & & & $\begin{array}{l}\text { Y1.2.3; } \\
\text { Y12.4 }\end{array}$ & \\
\hline \multirow{9}{*}{$\begin{array}{l}\text { Kinerja } \\
\text { Karyawan (Y2) }\end{array}$} & Keandalan (Y2.1) & Y2.1.1 - & $\mathrm{Y} 2.1 .2$ & Tidak ada \\
\hline & & Y2.1.4 & & \\
\hline & Kehadiran (Y2.2) & Y2.2.1 - & Y2.2.1; & Tidak ada \\
\hline & & Y2.2.3 & Y2.2.3 & \\
\hline & Kerjasama (Y2.3) & $\begin{array}{l}\text { Y2.3.1 - } \\
\text { Y2.3.3 }\end{array}$ & $\begin{array}{l}\text { Y2.3.2; } \\
\text { Y2.3.3 }\end{array}$ & Tidak ada \\
\hline & Kualitas pekerjaan & Y2.4.1 - & Y2.4.4; & Y2.4.6 \\
\hline & $(\mathrm{Y} 2.4)$ & Y2.4.6 & Y2.4.5; & \\
\hline & $\begin{array}{l}\text { Kuantitas pekerjaan } \\
(\mathrm{X} 2.5)\end{array}$ & $\begin{array}{l}\text { Y2.5.1 - } \\
\text { Y2.5.6 }\end{array}$ & Y2.5.6 & Tidak ada \\
\hline & Pengetahuan (Y2.6) & $\begin{array}{l}\text { Y2.6.1 - } \\
\text { Y2.6.3 }\end{array}$ & $\begin{array}{l}\text { Y2.6.1; } \\
\text { Y2.6.2; }\end{array}$ & Tidak ada \\
\hline
\end{tabular}

Pada Tabel 5 menunjukkan bahwa kekurangan wewenang untuk bisa melaksanakan tanggung jawab (X1.2) merefleksikan interelasi terbesar dalam menggambarkan pembangkit stress (stressor) dengan nilai loading factor sebesar 0.6935, diikuti dengan mengharapkan promosi hanya bisa mendapatkannya di perusahaan lain, bukan di perusahaan yang bersangkutan (X5.2) 0.6645 , posisi terjepit di antara atasan dan teman sekerja (X2.2) 0.66, perusahaan menuntut lebih dari kemampuan yang dimiliki (X3.3) 0.6531, mendapat tugas dan pekerjaan yang konflik dari dua atau lebih karyawan (X2.4) 0.637, instruksi kerja secara formal tidak melekat di perusahaan ini (X2.3) 0.6068, dan diberi banyak tugas sehingga susah mengaturnya (X4.3) 0.5957.

Untuk variabel stress kerja interelasi terbesar direfleksikan dengan item pernyataan merasa kesulitan bergaul dengan atasan (X1.2.9) dengan nilai loading factor sebesar 0.7567, diikuti dengan bekerja dengan peralatan yang tidak memadai atau kurang baik 
(Y1.2.8) sebesar 0.707, sering mengalami perubahan antara aktivitas yang membosankan dengan yang menantang (Y1.1.4) sebesar 0.7051 dan seterusnya (mengurutkan nilai terbesar sampai terkecil). Sementara untuk kinerja karyawan interelasi terbesar direfleksikan oleh item pernyataan mau mengambil resiko dan berpikir keras untuk selalu dapat bekerja dengan baik (Y2.4.3) mempunyai nilai loading factor sebesar 0.7628, merasa tanggung jawab atas pengembangan dan berniat mengevaluasi diri secara terus menerus (Y2.4.2) sebesar 0.7581, mampu membuat keputusan yang dapat menjawab permasalahan dalam waktu tertentu (Y2.4.1) sebesar 0.724, berusaha keras meningkatkan prestasi kerja (Y2.1.4) sebesar 0.7196 dan seterusnya.

Menurut Ghazali (2008), indikator yang mimiliki nilai loading factor di bawah 0.05, menunjukkan kekuatan merefleksikan sangat rendah sehingga harus didrop (dibuang). Dari pen-drop-an tersebut model perlu dieksekusi kembali dengan SmartPLS untuk menghasilkan loading faktor baru (Gambar 2).

Tabel 6. Nilai Loading Factor Pada Variabel Laten Stressor, Stres Kerja dan Kinerja Karyawan

\begin{tabular}{|c|c|c|c|c|}
\hline No & $\begin{array}{l}\text { Variabel } \\
\text { Laten }\end{array}$ & Kode & Keterangan Kode & Nilai Loading \\
\hline \multirow[t]{7}{*}{1} & Stressor & $\mathrm{X} 1.2$ & kekurangan wewenang & 0.6935 \\
\hline & $(\mathrm{X})$ & $\mathrm{X} 2.2$ & $\begin{array}{l}\text { posisi terjepit di antara atasan dan teman } \\
\text { sekerja }\end{array}$ & 0.66 \\
\hline & & $\mathrm{X} 2.3$ & instruksi kerja secara formal tidak melekat & 0.6068 \\
\hline & & $\mathrm{X} 2.4$ & $\begin{array}{l}\text { mendapat tugas dan pekerjaan yang } \\
\text { berisiko konflik }\end{array}$ & 0.637 \\
\hline & & X3.3 & Dituntut memiliki kemampuan lebih & 0.6531 \\
\hline & & $\mathrm{X} 4.3$ & $\begin{array}{l}\text { diberi banyak tugas sehingga susah } \\
\text { mengaturnya }\end{array}$ & 0.5957 \\
\hline & & X5.2 & mengharap promosi & 0.6645 \\
\hline \multirow[t]{13}{*}{2} & Stres & Y1.1.1 & mendapat tugas dengan tanggung jawab & 0.5742 \\
\hline & $\begin{array}{l}\text { Kerja } \\
(Y 1)\end{array}$ & Y1.1.3 & $\begin{array}{l}\text { yang lebih besar } \\
\text { merasakan ada persaingan }\end{array}$ & 0.6277 \\
\hline & & Y.1.1.4 & $\begin{array}{l}\text { sering mengalami perubahan antara } \\
\text { aktivitas }\end{array}$ & 0.7051 \\
\hline & & Y1.1.5 & $\begin{array}{l}\text { mengerjakan tugas administrasi secara } \\
\text { berlebihan. }\end{array}$ & 0.6603 \\
\hline & & Y1.1.6 & $\begin{array}{l}\text { merasakan kurang jam istirahat dalam } \\
\text { melakukan pekerjaan. }\end{array}$ & 0.5719 \\
\hline & & Y1.1.7 & $\begin{array}{l}\text { merasakan ada konflik dengan bagian } \\
\text { (departemen) lain }\end{array}$ & 0.5314 \\
\hline & & Y1.1.9 & merasa kurang dukungan dari atasan. & 0.5541 \\
\hline & & Y1.1.11 & merasa pendapatan saya kurang memadai & 0.6238 \\
\hline & & Y1.2.10 & $\begin{array}{l}\text { kurang karyawan untuk menangani suatu } \\
\text { tugas dengan memadai }\end{array}$ & 0.5121 \\
\hline & & Y1.2.11 & $\begin{array}{l}\text { kurang diberi kesempatan berpartisipasi } \\
\text { dalam pengambilan keputusan. }\end{array}$ & 0.6271 \\
\hline & & Y1.2.12 & $\begin{array}{l}\text { pengawasan atasan yang buruk dan kurang } \\
\text { memadai. }\end{array}$ & 0.6932 \\
\hline & & Y1.2.5 & $\begin{array}{l}\text { melakukan pekerjaan di luar tugas yang } \\
\text { seharusnya dikerjakan }\end{array}$ & 0.5922 \\
\hline & & Y1.2.6 & melakukan pekerjaan untuk karyawan lain & 0.5333 \\
\hline
\end{tabular}


Pujiwati dan Susanty: Analisis Fakor-Faktor Stressor Terhadap Stres Kerja...

\begin{tabular}{|c|c|c|c|c|}
\hline No & $\begin{array}{l}\text { Variabel } \\
\text { Laten }\end{array}$ & Kode & Keterangan Kode & Nilai Loading \\
\hline \multirow{18}{*}{3} & \multirow{18}{*}{$\begin{array}{l}\text { Kinerja } \\
\text { Karyaw } \\
\text { an (Y2) }\end{array}$} & Y1.2.7 & rekan sekerja tidak mau melakukan kerja. & 0.6214 \\
\hline & & $\mathrm{Y} 1.2 .8$ & $\begin{array}{l}\text { bekerja dengan peralatan yang tidak } \\
\text { memadai atau kurang baik }\end{array}$ & 0.707 \\
\hline & & Y1.2.9 & merasa kesulitan bergaul dengan atasan. & 0.7567 \\
\hline & & Y2.1.1 & $\begin{array}{l}\text { selalu dibutuhkan oleh klien dalam } \\
\text { memecahkan suatu masalah }\end{array}$ & 0.7058 \\
\hline & & Y2.1.3 & $\begin{array}{l}\text { mempunyai kemampuan dan kesediaan } \\
\text { dalam menyelesaikan tugas jabatan lebih } \\
\text { berat }\end{array}$ & 0.612 \\
\hline & & Y2.1.4 & $\begin{array}{l}\text { berusaha keras meningkatkan prestasi } \\
\text { kerja }\end{array}$ & 0.7196 \\
\hline & & $\mathrm{Y} 2.2 .2$ & $\begin{array}{l}\text { selalu menepati waktu dalam } \\
\text { melaksanakan tugas }\end{array}$ & 0.6079 \\
\hline & & Y2.3.1 & $\begin{array}{l}\text { bersedia untuk melibatkan diri sepenuhnya } \\
\text { dalam tugas-tugas jabatan yang berisiko }\end{array}$ & 0.6158 \\
\hline & & Y2..4.1 & $\begin{array}{l}\text { mampu membuat keputusan dalam waktu } \\
\text { tertentu }\end{array}$ & 0.724 \\
\hline & & $\mathrm{Y} 2.4 .2$ & $\begin{array}{l}\text { merasa bertanggung jawab atas } \\
\text { pengembangan dan berniat mengevaluasi } \\
\text { diri secara terus menerus }\end{array}$ & 0.7581 \\
\hline & & Y2.4.3 & $\begin{array}{l}\text { mengambil resiko dan berpikir keras untuk } \\
\text { selalu dapat bekerja dengan baik. }\end{array}$ & 0.7628 \\
\hline & & Y2.4.6 & $\begin{array}{l}\text { berusaha memahami data-data dan } \\
\text { informasi yang menjadi tanggung jawab. }\end{array}$ & 0.6618 \\
\hline & & Y2.5.1 & $\begin{array}{l}\text { biasa bekerja sesuai dengan target yang } \\
\text { telah ditetapkan }\end{array}$ & 0.6939 \\
\hline & & Y2..5.2 & $\begin{array}{l}\text { dalam melakukan tugas selalu berorientasi } \\
\text { pada keberhasilan. }\end{array}$ & 0.6465 \\
\hline & & Y2.5.3 & $\begin{array}{l}\text { ketika bekerja, tuntutan untuk } \\
\text { mengerjakan dengan hasil optimal sangat } \\
\text { tinggi. }\end{array}$ & 0.5596 \\
\hline & & Y2.5.4 & $\begin{array}{l}\text { merasa tertantang jika diberi beban dan } \\
\text { tanggung jawab yang lebih besar }\end{array}$ & 0.5651 \\
\hline & & Y2.5.5 & $\begin{array}{l}\text { merasa senang jika prestasi unit kerja lain } \\
\text { lebih baik, sehingga dapat dijadikan tolok } \\
\text { ukur dengan hasil kerja di tempat sendiri }\end{array}$ & 0.5502 \\
\hline & & Y2.6.3 & $\begin{array}{l}\text { mempunyai pengetahuan atas ruang } \\
\text { lingkup serta keterkaitan tugas-tugas } \\
\text { jabatan dengan jabatan-jabatan lain di } \\
\text { dalam atau di luar lingkup perusahaan }\end{array}$ & 0.5997 \\
\hline
\end{tabular}

Tabel 6 menunjukkan nilai loading factor untuk setiap indikator setelah dilakukan pen-dop-an > 0.50. Dengan demikian kriteria untuk Convergent Validity (reliabilitas indikator) telah terpenuhi. Sama halnya dengan stressor, jika indikator-indikator yang terdapat pada variabel stress kerja dan kinerja karyawan menggambarkan refleksi dari kedua variabel tersebut, maka nilai korelasi indikator-indikator harus lebih besar dibandingkan korelasi indikator-indikator terhadap variabel laten lainnya. 


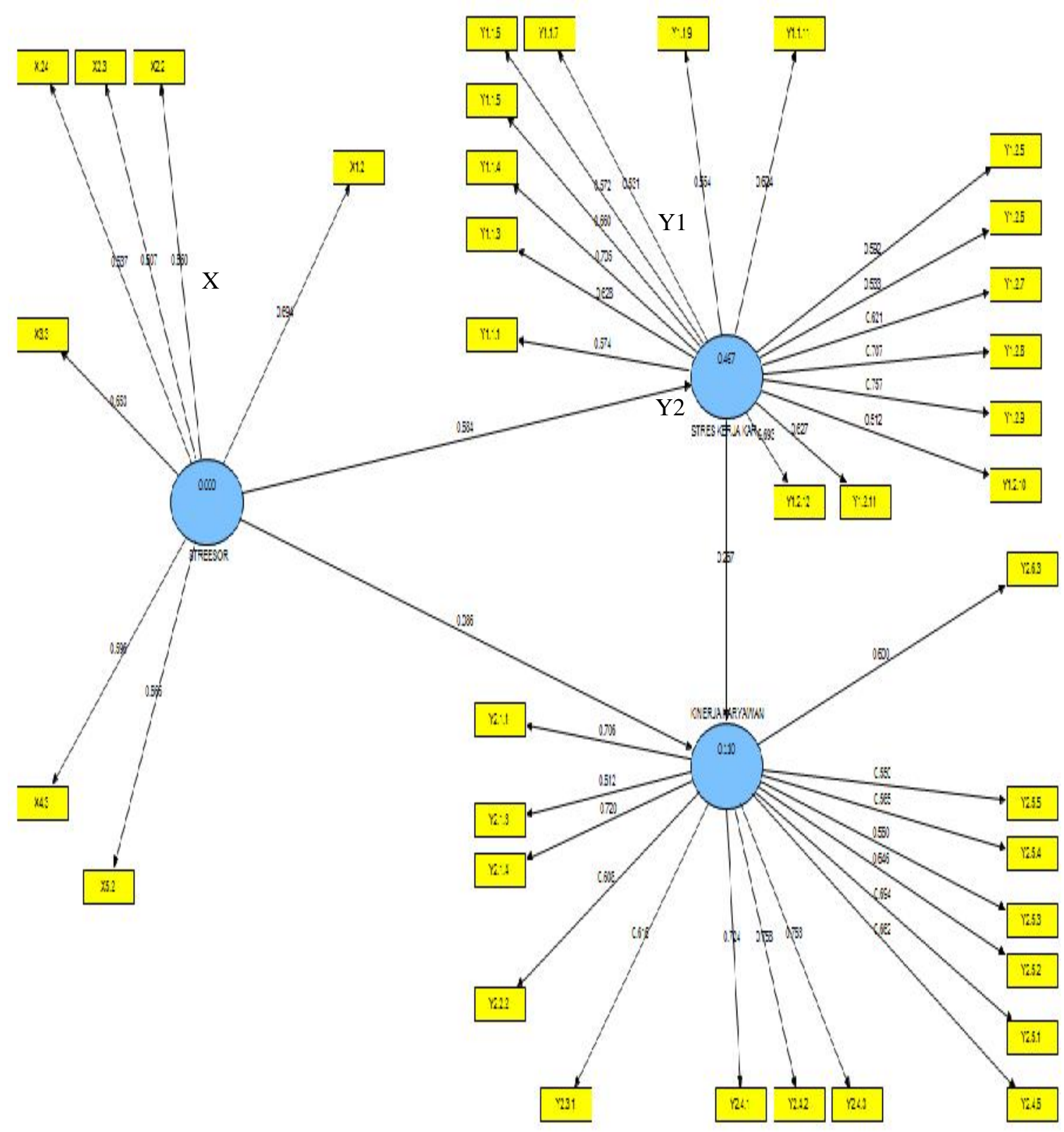

Gambar 2. Model Pengaruh Stressor Terhadap Stres Kerja dan Kinerja Karyawan, Setelah Mengalami Pen-drop-an

Discriminat validity. Pada Tabel 7 menunjukkan nilai korelasi variabel stressor, stress kerja dan kinerja karyawan dengan masing-masing indikatornya. Jika indikator-indikator yang terdapat pada variabel stressor menggambarkan refleksi dari stressor, maka nilai korelasi indikator-indikator ini terhadap stressor harus lebih besar dibandingkan korelasi indikator-indikator tersebut terhadap variabel laten lainnya. Tabel 7 menunjukkan bahwa nilai korelasi indikator terhadap stressor lebih besar jika dibandingkan dengan korelasi indikator yang sama terhadap variabel laten lainnya. Hal tersebut membuktikan bahwa model reflektif stressor pada penelitian ini valid. 
Tabel 7. Nilai Cross Loading

\begin{tabular}{cccc}
\hline Indikator & Kinerja Karyawan & Stressor & Stres Kerja \\
\hline X2.4 & 0.1538 & 0.637 & 0.4628 \\
X1.2 & 0.0972 & 0.6935 & 0.4701 \\
X2.2 & 0.1722 & 0.66 & 0.3842 \\
X2.3 & 0.0034 & 0.6068 & 0.3842 \\
X3.3 & 0.2897 & 0.6531 & 0.4214 \\
X4.3 & 0.2002 & 0.5957 & 0.4234 \\
X5.2 & 0.2428 & 00.6645 & 0.4816 \\
Y1.1.1 & 0.1714 & 0.4692 & 0.5742 \\
Y1.1.11 & 0.0327 & 0.4489 & 0.6238 \\
Y1.1.3 & 0.2033 & 0.4617 & 0.6277 \\
Y1.1.4 & 0.254 & 0.4617 & 0.6277 \\
Y1.1.5 & 0.2762 & 0.55 & 0.6603 \\
Y1.1.6 & 0.4187 & 0.3311 & 0.5719 \\
Y1.1.7 & 0.0373 & 0.3011 & 0.5314 \\
Y1.1.9 & 0.0497 & 0.372 & 0.5541 \\
Y1.2.10 & 0.0691 & 0.2688 & 0.5121 \\
Y1.2.11 & 0.2196 & 0.373 & 0.6271 \\
Y1.2.12 & 0.2973 & 0.4764 & 0.6932 \\
Y1.2.5 & 0.236 & 0.3918 & 0.5922 \\
Y1.2.6 & 0.1761 & 0.4583 & 0.5333 \\
Y1.2.7 & 0.1776 & 0.3862 & 0.6214 \\
Y1.2.8 & 0.1728 & 0.4565 & 0.707 \\
Y1.2.9 & 0.2531 & 0.5018 & 0.7567 \\
Y2.1.1 & 0.7058 & 0.1698 & 0.2576 \\
Y2.1.3 & 0.612 & 0.1467 & 0.1929 \\
Y2.1.4 & 0.7196 & 0.2495 & 0.2991 \\
Y2.2.2 & 0.6079 & 0.1258 & 0.1572 \\
Y2.3.1 & 0.6158 & 0.1515 & 0.1876 \\
Y2.4.1 & 0.724 & 0.2574 & 0.3262 \\
Y2.4.2 & 0.7581 & 0.1104 & 0.1576 \\
Y2.4.3 & 0.7628 & 0.1569 & 0.1845 \\
Y2.4.6 & 0.6618 & 0.145 & 0.1653 \\
Y2.5.1 & 0.6939 & 0.2193 & 0.2385 \\
Y2.5.2 & 0.6465 & 0.1665 & 0.2093 \\
Y2.5.3 & 0.5596 & 0.0648 & 0.1041 \\
Y2.5.4 & 0.5651 & 0.1941 & 0.1688 \\
Y2.5.5 & 0.5502 & 0.0517 & 0.1278 \\
Y2.6.3 & 0.5997 & 0.2216 & 0.2067 \\
\hline & & &
\end{tabular}

Average Variance Extracted (AVE). Validitas menunjukkan suatu pengujian benarbenar konsisten mengukur apa yang seharusnya diukur, dalam hal ini bagaimana indikator-indikator (baik stressor, stres kerja maupun kinerja karyawan) konsisten 
mengukur variabel latennya masing-masing. Hal ini dapat digambarkan oleh besaran nilai Average Variance Extracted (AVE). Nilai AVE stressor, stress kerja dan kinerja karyawan dapat dilihat pada Tabel 8.

Tabel 8. Nilai AVE untuk Variabel Stressor, Stres Kerja dan Kinerja Karyawan

\begin{tabular}{lc}
\hline \multicolumn{1}{c}{ Variabel } & AVE \\
\hline Kinerja karyawan & 0.4301 \\
Stressor & 0.4162 \\
Stres Kerja & 0.387 \\
\hline
\end{tabular}

Nilai-nilai yang disajikan pada Tabel 8 dapat disimpulkan bahwa indikator untuk setiap laten kurang konsisten mengukur masing-masing variabel latennya.

Composite Reliability ( $(\rho)$. Composite reliability ( $\rho \mathrm{c})$ menunjukkan suatu pengujian terhadap kestabilan dan konsistensi internal indikator yang baik. Dalam hal ini bagaimana indikator-indikator baik stressor, stress kerja maupun kinerja karyawan konsisten mengukur variabel latennya masing-masing. Hal ini dapat digambarkan oleh besaran nilai Composite reliability $(\rho c)$.

Tabel 9. Nilai Composite Reliability

\begin{tabular}{cc}
\hline Variabel & Composite Reliability $\left(\rho_{\mathrm{c}}\right)$ \\
\hline Kinerja Karyawan & 0.918 \\
Stressor & 0.8328 \\
Stres Kerja & 0.9089 \\
\hline
\end{tabular}

Tabel 9 menunjukkan nilai stressor, stress kerja karyawan maupun kinerja karyawan adalah masing-masing sebesar 0.833, 0.909, dan 0.918. Dari hasil pengolahan SEM SmartPLS, nilai $\rho$ berada di atas 0.5 sehingga dapat disimpulkan bahwa indikator yang digunakan untuk setiap laten memiliki kestabilan dan konsisten yang baik.

Evaluasi Model struktural (Inner Model). Menilai inner model adalah mengevaluasi pengaruh antar variabel laten dan pengujian hipotesis. Model struktural dievaluasi dengan menggunakan $R$-square untuk variabel endogen dengan membandingkan thitung dengan $\mathrm{t}_{\text {tabel }}\left(\mathrm{tt}_{\mathrm{abel}}\right.$ pada tingkat kepercayaan $95 \%$ adalah 1.96$)$.

Penelitian ini memiliki 2 (dua) variabel endogen yaitu variabel stress kerja dan kinerja karyawan. Kedua variabel endogen tersebut dipengaruhi oleh stressor (Gambar 1). Hasil pengolahan SEM SmartPLS pada tabel 10 menunjukkan bahwa $R$-Square stressor terhadap stress kerja karyawan dan kinerja karyawan sebesar sebesar 0.1102 dan 0.4672. Hal ini berarti kinerja karyawan dipengaruhi oleh stressor sebesar $11,02 \%$ dan sisanya dipengaruhi oleh faktor lain. Dan stress kerja karyawan dipengaruhi oleh stressor sebesar $46,72 \%$ dan sisanya dipengaruhi oleh faktor lain. Stress kerja karyawan dipengaruhi oleh stressor sebesar $46,72 \%$ dan sisanya dipengaruhi oleh faktor lain. Menurut Chin (1998) dalam Ghozali (2008) bahwa hasil $R$-Square sebesar 0.67, 0.33 dan 0.19 untuk variabel laten endogen dalam model struktural, masing-masing mengindikasikan bahwa model "baik", "moderat", dan "lemah". Berdasarkan teori 
tersebut dan nilai $R$-Square pada variabel laten penelitian ini menunjukkan bahwa kategori model yang diterangkan termasuk ke dalam model yang modera dan lemah.

Tabel 10. R-Square Stressor terhadap stress kerja karyawan dan kinerja karyawan

\begin{tabular}{lrrrr}
\hline & \multicolumn{2}{c}{ Composite } & \\
& \multicolumn{1}{c}{ AVE } & Reliability & \multicolumn{1}{c}{ R Square } & Cronbachs Alpha \\
\hline Kinerja Karyawan & 0.4301 & 0.918 & 0.1102 & 0.9053 \\
Streesor & 0.4162 & 0.8328 & 0 & 0.7664 \\
Stres Kerja Karyawan & 0.387 & 0.9089 & 0.4672 & 0.8933 \\
\hline
\end{tabular}

Sumber: hasil data primer yang diolah smartPLS, 2013

Untuk melakukan pengujian hipotesis dilakukan dengan melihat analisis bootstraping pada path coefficients, yaitu dengan membandingkan nilai $t_{\text {hitung }}$ dengan $\mathrm{t}_{\text {tabel. }}$. Hasil analisis path coefficients dapat dilihat pada tabel 11 dengan nilai $t_{\text {abel }} 1.96$ (pada selang kepecayaan 95\%) untuk keseluruhan variabel laten.

Tabel 11. Nilai Hasil Analisis Path Coefficients

\begin{tabular}{cc}
\hline Variabel & T Statistics $(|\mathrm{O} / \mathrm{STERR}|)$ \\
\hline Stressor $\rightarrow$ Kinerja Karyawan & 0.4104 \\
Stressor $\rightarrow$ Stres Kerja Karyawan & 12.0641 \\
Stres Kerja $\rightarrow$ Kinerja Karyawan & 1.3737 \\
\hline
\end{tabular}

Sumber: hasil data primer yang diolah smartPLS, 2013

Hipotesis 1: Pembangkit stres kerja (stressor) berpengaruh signifikan terhadap stres kerja karyawan.

Pengujian hipotesis pertama diterima karena pada hasil analisis diperoleh bahwa $t_{\text {hitung }}=$ 12.0641 lebih besar dibanding $\mathrm{t}_{\text {tabel }}=1.96$. Hal ini menunjukkan bahwa stressor di kantor Sekjen Kemenkeu berpengaruh positif secara signifikan terhadap stress kerja karyawan. Penelitian ini memperkuat penelitian Ralston et.al (2010) yang menyatakan ambiguitas yang merupakan salah satu indikator dalam stressor mampu mempengaruhi secara signifikan terhadap ketegangan/stress.

Hipotesis 2: Pembangkit stres kerja (stressor) berpengaruh signifikan terhadap kinerja karyawan

Pengujian hipotesis kedua ditolak karena pada hasil analisis diperoleh bahwa $t_{\text {hitung }}=$ 0.4104 lebih kecil dibanding $t_{\text {tabel }}=1.96$. Hal ini menunjukkan bahwa stressor di kantor Sekjen Kemenkeu tidak berpengaruh secara signifikan kinerja karyawan. Penelitian ini tidak relevan dengan hasil penelitian Beehr et.al (2000) yang menyatakan stressor mempunyai hubungan yang signifikan dengan kinerja. Hal ini diduga dipengaruhi oleh karakteristik pekerjaan yang ada Sekjen Kementrian Keuangan yang bersifat sangat administratif.

Hipotesis 3: Stres kerja karyawan berpengaruh signifikan terhadap kinerja karyawan Pengujian hipotesis ketiga ditolak karena pada hasil analisis diperoleh bahwa $t_{h i t u n g}=$ 1.3737 lebih kecil dibanding $\mathrm{t}_{\text {tabel }}=1.96$. Hal ini menunjukkan bahwa stres kerja tidak berpengaruh secara signifikan terhadap kinerja. Penelitian ini tidak relevan dengan 
penelitian yang telah dilakukan oleh Putra dan Rahyuda (2503:2015) yang mengatakan bahwa stess stres kerja mampu mempengaruhi kinerja. Yang berarti semakin rendah stres kerja yang dirasakan oleh para pegawai, maka menyebabkan kinerjanya pegawai tersebut akan naik.Namun lain halnya dengan karyawan yang ada di Sekjen Kementrian Keuangan dimana stress kerja tidak berpengaruh terhadap kinerja karyawan.

\section{PENUTUP}

Hasil penelitian menunjukkan bahwa kekurangan wewenang untuk bisa melaksanakan tanggung jawab menjadi faktor utama dalam pembangkit stress (stressor) sedangkan kesulitan bergaul dengan atasan menjadi faktor penyebab stress kerja. Sementara yang menjadi faktor utama dalam meningkatkan kinerja karyawan adalah mengambil resiko dan berpikir keras untuk selalu dapat bekerja dengan baik.

Hasil penelitian juga menunjukkan bahwa stressor di pegawai Sekjen Kemenkeu berpengaruh positif secara signifikan terhadap stress kerja karyawan. Hal ini dapat diartikan bahwa semakin banyak stressor, maka semakin tinggi stress kerja pegawai begitupun sebaliknya. Pembangkit stres kerja (stressor) berpengaruh signifikan terhadap kinerja karyawan. Hipotesis ini ditolak yang berarti bahwa tidak ada pengaruh stressor terhadap kinerja karyawan. Stres kerja karyawan berpengaruh signifikan terhadap kinerja karyawan, hipotesis ini ditolak. Hal ini berarti stress kerja tidak mempengaruhi kinerja pegawai.

\section{DAFTAR RUJUKAN}

Beehr, Terry A; Jex, Steve M; Stacy, Beth A; Murray, Marshall A. (2000) "Work Stressors And Coworker Support As Predictors Of Individual Strain And Job Performance". Journal of Organizational Behavior. 21 (4), 391-405

Canadian Centre for Occupational Health and Safety. (1999) Workplace Stress-General. Diunduh dari: http://www.ccohs.ca/oshanswer/psychosocial/stress.html tgl 17 Januari 2013

Ghozali I. (2008) Structural Equation Modeling Metode Alternatif dengan Partial Least Square. Ed. 2. Semarang: Badan Penerbit Universitas Diponegoro.

Gibson, C.B., Zellmer. \& Schwab. (1993) "Team Effectiveness in Multinational Organization: Evaluation Accross Context". Group And Organization Management. 28 (4), 444-475.

Hair, J.F., W.C. Black, B.J. Babin, R.E. Anderson, R.L.Tatham, (2006) Multivariate Data Analysis, $6^{\text {th }}$ Ed., New Jersey: Prentice Hall

Ivancevich, J.M., Matesson, M.T. (1997) Organization Behavior and Management. 3rd edition. Homewood.

Jams, V.M, (1986) Understanding Human Behavior. $5^{\text {th }}$ edition. CBS College Publish

Ma'rifah, D. (2004) "Pengaruh Motivasi Kerja dan Budaya Organisasi terhadap Kinerja Pekerja Sosial pada Unit Pelaksana Teknis Dinas Sosial Propinsi Jawa Timur". Tesis, Surabaya: Program Pascasarjana Universitas Airlangga

Makhbul, Z.M., Idrus, D. (2009) "Work Stress Issues in Malaysia”. Malaysia Labour Review. 3(2), 13-26.

Mangkuprawira S. (2009) Horizon: Bisnis, Manajemen dan Sumberdaya Manusia. Bogor: IPB Press 
Milbourn, G. (2006) "Teaching the Job Stress Audit to Business School Student: Cause, Meansures, Reduction". Journal of American Academy of Business. 8 (2), 44-50.

Putra. Dharma Surya I.B.K, Rahyuda. Ganesha Agoes. (2015) "Pengaruh Lingkungan Kerja Fisik Dan Stres Kerja Terhadap Kinerja Pegawai Di Upt. Pengujian Kendaraan Bermotor Dinas Perhubungan Kota Denpasar". E-Jurnal Manajemen Unud, 4 (9), 2015- 2503

Rahmawati, S. (2009) "Analisis Stres Kerja Karyawan pada PT Bank Rakyat Indonesia (Persero) Tbk Cabang Bogor”. Jurnal Manajemen IPB.5 (2), 111-122.

Ralston, David A; Lee, Chay Hoon; Perrewé, Pamela L; Van Deusen, Cheryl; Vollmer, Günther R; dkk. (2010) "A multi-society examination of the impact of psychological resources on stressor-strain relationships". Journal of International Business Studies, 41 (4), 652-670.

Shaikh, F.M.,Syed, A.S.G., Luhno,H.D.,\&Kartio,M.A. (2011) "Role Conflict and Role Ambiguity as Factors in Work Stress among Manager: Case Strudy of Manufacturing Sector in Pakistan". Terengganu International Management and Bussiness Journal. 1(2), 36-45. 